\title{
Marketing strategy determinants of export performance: a meta-analysis
}

\author{
Leonidas C. Leonidou ${ }^{\mathrm{a}}$, Constantine S. Katsikeas ${ }^{\mathrm{b}}$, Saeed Samiee ${ }^{\mathrm{c}, *}$ \\ ${ }^{\mathrm{a}}$ University of Cyprus, Cyprus \\ ${ }^{\mathrm{b}}$ Cardiff Business School, Cardiff University, UK \\ ${ }^{\mathrm{c}}$ College of Business Administration, The University of Tulsa, 600 S. College Avenue, Tulsa, OK 74104, USA
}

\begin{abstract}
Identifying the marketing strategy elements that influence export performance has been the subject of sizeable empirical research. However, the findings reported in the literature are characterized by fragmentation and diversity, limiting theory development and improvement of management practice in the field. This article aims to synthesize extant knowledge on the subject based on a meta-analysis of empirical studies on the export marketing strategy-performance relationship. The assessment reveals that: (a) although many marketing strategy variables demonstrate positive effects on overall export performance, the relationship is not always significant; (b) of the export performance measures examined in various studies, stronger effects are observed in relation to export proportion of sales; and (c) time of study, geographic focus, and product type had a limited impact on the effect of marketing strategy elements on export performance. Implications for export management and future research are discussed. (C) 2001 Elsevier Science Inc. All rights reserved.
\end{abstract}

Keywords: Export performance; Export marketing strategy; Meta-analysis

The intensification of competition on a global scale has led to an increasing number of firms seeking opportunities in international markets to achieve their objectives, as well as to safeguard their market position and survival. Exporting has traditionally been the most popular mode of international market entry, favored especially by smalland medium-sized firms. In its most basic form, exporting requires minimal financial, human, and other resource commitments, involves low investment and financial risks, and allows for greater structural and strategic flexibility in the market (Young et al., 1989). However, to achieve success in export markets is not an easy task, due largely to the multiple, diverse, and idiosyncratic nature of foreign environments (Samiee and Walters, 1990; Czinkota and Ronkainen, 1998).

Substantial empirical research has been undertaken to identify factors responsible for successful exporting. ${ }^{1}$ Specifically, research attention has focused on five major groups of variables influencing export performance: (a) managerial

\footnotetext{
* Corresponding author. Tel.: +1-918-631-2019; fax: +1-918-631-2083

E-mail address: samiee@utulsa.edu (S. Samiee).

${ }^{1}$ For an overview of these studies, see Madsen (1987), Aaby and Slater (1989), Gemünden (1991), Chetty and Hamilton (1993), and Zou and Stan (1998).
}

- personal, experiential, attitudinal, behavioral, and allied traits of the exporting firm's decision-maker(s), ${ }^{2}$ (b) organizational - elements pertaining to the characteristics, operations, resources, and objectives of the exporting organization; (c) environmental - factors shaping the task and macro-environments within which exporters operate in both domestic and international markets; (d) targeting - the identification, selection, and segmentation of international markets; and (e) marketing mix variables - the company's export product, pricing, distribution, and promotion strategy (Miesenböck, 1988; Ford and Leonidou, 1991).

The relationships of these groups of variables with export performance have been conceptualized in several studies (e.g., Gemünden, 1991; Holzmüller and Kasper, 1991; Axinn, 1994; Cavusgil and Zou, 1994; da Rocha and Christensen, 1994). Our analysis of these studies revealed three distinct sets of variables on which a simplified export performance model can be based. The first group includes

\footnotetext{
${ }^{2}$ These can be classified into objective or subjective depending on whether they refer to personal and cultural, or behavioral and attitudinal, traits of the decision-maker. They can also be divided into factors that either have a specific international connotation or are relatively general. These two typologies can subsequently be combined into four categories of managerial factors: general-objective, specific-objective, general-subjective, and specific-subjective (Leonidou et al., 1998).
} 


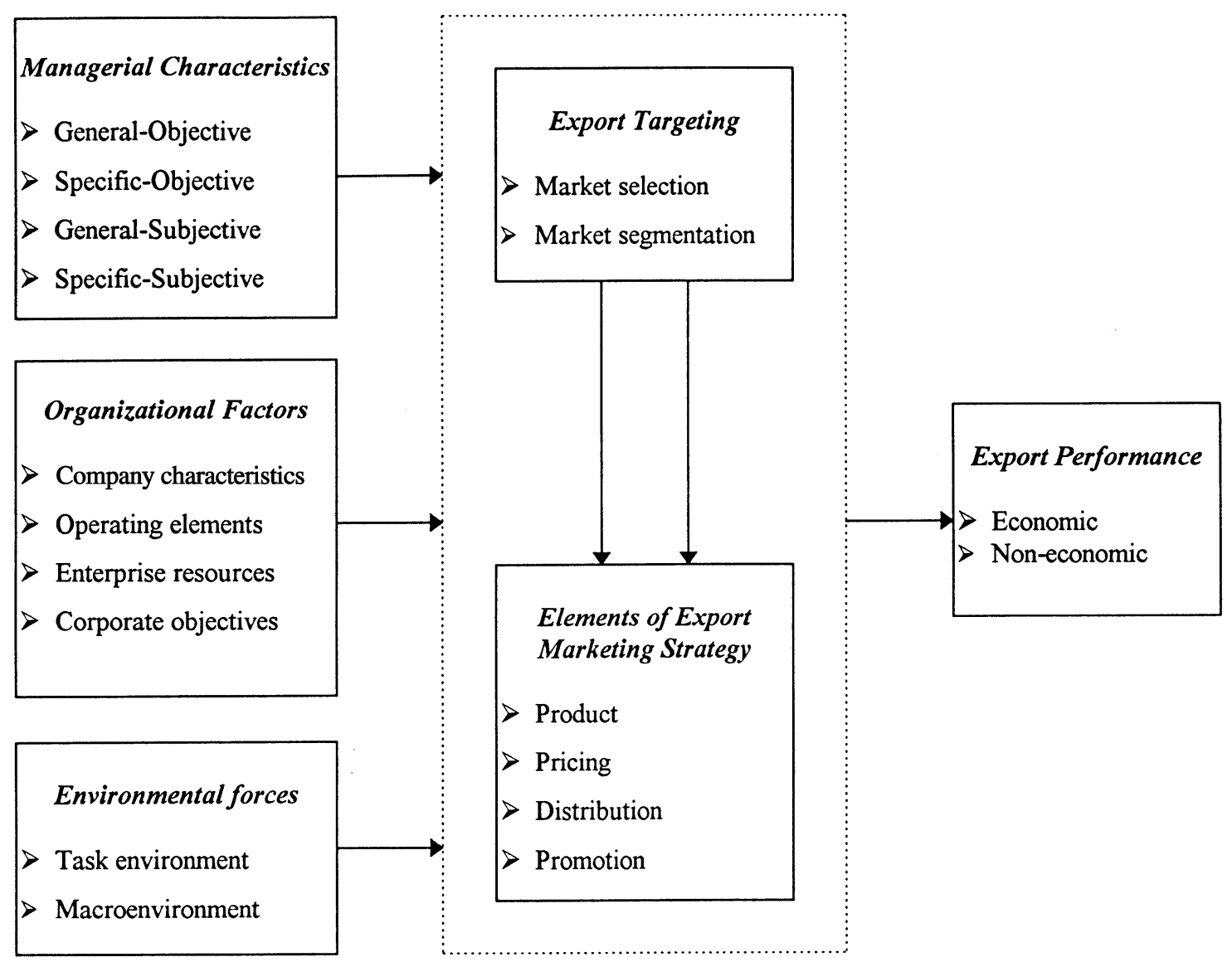

Fig. 1. A synthesis of export performance models.

variables relating to managerial, organizational, and environmental factors that serve as antecedent forces in the sense that they indirectly affect export performance. The second group is comprised of variables pertaining to the firm's export marketing strategy (i.e., targeting and marketing mix programs) that are linked directly to export performance. The third group consists of economic and noneconomic measures of firms' export performance. The basic operating mechanism of the model implies a unidirectional causal relationship: managerial, organizational, and environmental factors influence the firm's export targeting and marketing mix, that in turn affect export performance. ${ }^{3}$ As shown in Fig. 1, these influences represent a summary of earlier conceptual work and constitute the basis for this review. ${ }^{4}$

\footnotetext{
${ }^{3}$ It is noteworthy that none of the studies under review questions the direction of causality in the export marketing strategy-performance relationship. However, in view of the cross-sectional nature of the data in the vast majority of the studies reviewed, caution should be exercised when drawing cause-effect inferences.

${ }^{4}$ Apart from linkages between the three sets of factors, variables within each group may also be interconnected. For instance, organizational variables might affect managerial characteristics, and market targeting parameters may influence export marketing mix ingredients. Further, some researchers consider this model as part of a broader framework covering the firm's domestic business activities as well (Kamath et al., 1987).
}

In the absence of mid-level theories in exporting, the model shown in Fig. 1 is suggested as a preliminary attempt to move in this direction (Kamath et al., 1987; Axinn, 1994). ${ }^{5}$ To test its validity and generalizability, however, it is first necessary to review, synthesize, and assess relevant empirical research. Such an undertaking is important at this stage for three reasons. First, most studies represent isolated and uncoordinated attempts aimed to investigate and test only certain dimensions of the overall model. Second, investigation efforts took place at different points in time, in varying geographic contexts and industrial settings, with a possible exogenous effect on the resulting findings. Third, research designs were diverse, sometimes employing inconsistent terminologies, definitions, and operationalizations of variables. As a result, research findings are fragmented,

\footnotetext{
5 The lack of mid-level theories in exporting can be attributed to four major problems endemic to exporting research: (a) the tendency to study exporting in isolation from other strategic actions, such as the firm's domestic strategy; (b) the fact that the dominant methodology in this field of research is that of logical empiricism; (c) the focus on different industries, countries, and time periods, as well as the existence of dissimilar research methodologies; and (d) the emphasis on establishing relationships between dependent and independent variables, without linking the results obtained to a well-defined research program (Kamath et al., 1987; Axinn, 1994).
} 
causing confusion and misunderstanding with regard to those variables that significantly affect export performance.

This study aims to synthesize extant knowledge on variables influencing export performance by means of meta-analysis. However, lacking sufficient research on the association of antecedent factors with export marketing strategy, the scope of this study is confined to that part of the export performance model focusing on the relationship between marketing strategy variables (i.e., targeting and the marketing mix elements) and performance. ${ }^{6}$ This endeavor contributes to the body of literature that seeks to establish the influence of strategy on performance (cf. Greenley, 1986; Pearce et al., 1987; Asnoff, 1991; Mintzberg, 1991; Miller and Cardinal, 1994) from an export marketing perspective. The link between export marketing strategy and export performance has not yet been clearly established. Examination of such a link is critical, however, as it can inform and direct corporate policy in three important ways: (a) scarce company resources can be directed to those marketing strategy elements known to enhance export performance; (b) marketing strategies can be tailored to those performance dimensions most conducive to the fulfillment of export objectives; and (c) marketing strategies can be adjusted according to important context-specific factors.

In Section 1, the method employed to systematically identify, collect, and analyze all relevant empirical studies on the export marketing strategy-performance relationship is explained. Subsequently, certain important methodological features of the studies reviewed are examined. The results of our meta-analysis are then presented. Finally, conclusions and implications are drawn for export management as well as for future research directions.

\section{Method}

\subsection{Search criteria}

Six criteria were developed to screen studies for inclusion in this analysis. First, although the major part of empirical research in exporting is fairly recent, for the sake of completeness, all research conducted since 1960 has been considered. Second, the focus of the study must be on the relationship between marketing strategy variables and export performance, either as a primary objective or as part of

\footnotetext{
${ }^{6}$ A large number of studies have examined the direct effect of organizational and managerial variables on export performance. A review of the literature revealed that among a list of 17 organizational factors, those that had a systematic positive effect on export performance referred to the availability and quality of enterprise resources, particularly human capital and research and development (Leonidou, 1998). In the case of managerial variables, from a list of 17 elements, those exhibiting the greatest impact on export performance include professional experience, language proficiency, risk tolerance, and commitment of the decisionmaker(s) (Leonidou et al., 1998).
}

a wider research design. ${ }^{7}$ Third, the emphasis is on studies that examined business concerns engaged in the manufacturing of consumer and/or industrial products. Fourth, the focus is on the exporting phase of the firm's internationalization process, defined as the transfer of goods across national boundaries using direct or indirect methods. Fifth, the unit of analysis is at the micro business level, namely the firm or business venture. Sixth, the data must be collected from primary sources and the results presented in a useful form for meta-analytical purposes.

\subsection{Search method}

Studies fulfilling the eligibility criteria were taken from publications in journals, books, and conference proceedings using a combination of computerized and manual bibliographic search methods. Although the computerized literature search provided information on articles contained in journals, the manual method was effective in tracing papers included in books and conference proceedings. This led to the identification of 36 studies contained in 17 publications, originating mainly in North America and Europe. Although this is a relatively small number, given the large body of published exporting literature, it is in line with other reviews of empirical strategy-performance studies (e.g., Pearce et al., 1987; Miller and Cardinal, 1994).

\subsection{Coding process}

A sample of eligible studies was randomly selected and analyzed to elicit content categories into which the study data could be easily coded; a three-part coding form resulted. The first part comprised information on key methodological characteristics of each study (i.e., unit of analysis, sampling method, and analytical techniques). The second part included specific export performance measures; the 12 measures identified in the studies were coded into eight categories. The third part contained a list of 32 marketing strategy variables, each assessed for the degree to which it related to export performance using $p$-values, and the positive or negative direction of this association. When a study employed more than one export performance measure, a separate list of marketing strategy variables was utilized.

\subsection{Analytical method}

Each coding form was examined for completeness and consistency and a computer data file was created. Descrip-

\footnotetext{
${ }^{7}$ Within the context of this study, marketing strategy decision areas consist of those pertaining to selecting and segmenting export markets, and subsequently developing, pricing, distributing, and promoting products in these markets. Export performance refers to the economic, behavioral, or other outcomes resulting from the firm's export business operations.
} 
Table 1

Profile of export marketing strategy research

\begin{tabular}{|c|c|c|c|c|c|c|c|c|c|c|}
\hline \multirow[b]{3}{*}{$\begin{array}{l}\text { Methodology } \\
\text { characteristics }\end{array}$} & \multicolumn{10}{|c|}{ Study characteristics } \\
\hline & \multirow[b]{2}{*}{$\begin{array}{l}\text { Total } \\
(n=36)\end{array}$} & \multicolumn{3}{|c|}{ Time of study } & \multicolumn{3}{|c|}{ Geographic focus } & \multicolumn{3}{|c|}{ Product type } \\
\hline & & $\begin{array}{l}1970 \mathrm{~s} \\
(n=6)\end{array}$ & $\begin{array}{l}1980 \mathrm{~s} \\
(n=19)\end{array}$ & $\begin{array}{l}1990 \mathrm{~s} \\
(n=11)\end{array}$ & $\begin{array}{l}\text { America } \\
(n=17)\end{array}$ & $\begin{array}{l}\text { Europe } \\
(n=12)\end{array}$ & $\begin{array}{l}\text { Other } \\
(n=7)\end{array}$ & $\begin{array}{l}\text { Consumer } \\
(n=5)\end{array}$ & $\begin{array}{l}\text { Industrial } \\
(n=12)\end{array}$ & $\begin{array}{l}\text { Both } \\
(n=19)\end{array}$ \\
\hline \multicolumn{11}{|l|}{ Unit of analysis } \\
\hline Exporting firm & 31 & 4 & 17 & 10 & 13 & 11 & 7 & 5 & 10 & 16 \\
\hline Export venture & 5 & 2 & 2 & 1 & 4 & 1 & - & - & 2 & 3 \\
\hline \multicolumn{11}{|l|}{ Company size } \\
\hline Small & 34 & 5 & 18 & 11 & 16 & 11 & 7 & 4 & 12 & 18 \\
\hline Medium & 32 & 5 & 16 & 11 & 15 & 10 & 7 & 4 & 10 & 18 \\
\hline Large & 23 & 5 & 9 & 9 & 10 & 6 & 7 & 3 & 8 & 12 \\
\hline N.A. & 2 & 1 & 1 & - & - & 1 & 1 & 1 & 1 & - \\
\hline \multicolumn{11}{|l|}{ Industry coverage } \\
\hline One to three industries & 9 & 2 & 6 & 1 & 4 & 5 & - & 5 & 4 & - \\
\hline Four to seven industries & 10 & 1 & 8 & 1 & 4 & 3 & 3 & - & 5 & 5 \\
\hline Eight or more industries & 3 & - & 1 & 2 & 2 & - & 1 & - & 1 & 2 \\
\hline N.A. & 14 & 3 & 4 & 7 & 7 & 4 & 3 & - & 2 & 12 \\
\hline \multicolumn{11}{|l|}{ Sampling design } \\
\hline Probability & 20 & 3 & 11 & 6 & 7 & 7 & 6 & 2 & 7 & 11 \\
\hline Nonprobability & 11 & 3 & 4 & 4 & 5 & 5 & 1 & 3 & 2 & 6 \\
\hline N.A. & 5 & - & 4 & 1 & 5 & - & - & - & 3 & 2 \\
\hline \multicolumn{11}{|l|}{ Response rate } \\
\hline Below 30\% & 14 & 1 & 8 & 5 & 10 & 1 & 3 & - & 6 & 8 \\
\hline $30 \%$ or above & 20 & 3 & 11 & 6 & 7 & 9 & 4 & 3 & 6 & 11 \\
\hline N.A. & 2 & 2 & - & - & - & 2 & - & 2 & - & - \\
\hline \multicolumn{11}{|l|}{ Sample size $e^{\mathrm{a}}$} \\
\hline Below 150 & 24 & 4 & 15 & 5 & 12 & 10 & 2 & 5 & 10 & 9 \\
\hline 150 or above & 12 & 2 & 4 & 6 & 5 & 2 & 5 & - & 2 & 10 \\
\hline \multicolumn{11}{|l|}{ Nonresponse bias } \\
\hline Tested & 11 & 1 & 5 & 5 & 7 & 2 & 2 & - & 5 & 6 \\
\hline Nontested & 25 & 5 & 14 & 6 & 10 & 10 & 5 & 5 & 7 & 13 \\
\hline \multicolumn{11}{|l|}{ Data collection $^{\mathrm{a}}$} \\
\hline Mail & 34 & 6 & 19 & 9 & 16 & 11 & 7 & 4 & 12 & 18 \\
\hline Telephone & 6 & - & 4 & 2 & 3 & 2 & 1 & 1 & 2 & 3 \\
\hline Personal & 10 & 3 & 5 & 2 & 4 & 5 & 1 & 4 & 3 & 3 \\
\hline \multicolumn{11}{|l|}{ Key informant ${ }^{\mathrm{a}}$} \\
\hline CEO/President & 4 & 1 & 2 & 1 & 3 & - & 1 & - & 1 & 3 \\
\hline Export officer & 8 & - & 4 & 4 & 3 & 2 & 3 & - & 3 & 5 \\
\hline Marketing manager & 4 & 1 & 2 & 1 & 1 & 1 & 2 & - & 1 & 3 \\
\hline Other executive & 7 & - & 5 & 2 & 5 & 1 & 1 & 1 & 4 & 2 \\
\hline N.A. & 16 & 4 & 9 & 3 & 5 & 8 & 3 & 4 & 3 & 9 \\
\hline \multicolumn{11}{|l|}{ Strategy measures ${ }^{\mathrm{a}}$} \\
\hline One to three variables & 12 & 2 & 6 & 4 & 7 & 3 & 2 & 2 & 5 & 5 \\
\hline Four to six variables & 14 & 3 & 7 & 4 & 6 & 6 & 2 & 3 & 3 & 8 \\
\hline Seven variables or more & 10 & 1 & 6 & 3 & 4 & 3 & 3 & - & 4 & 6 \\
\hline \multicolumn{11}{|l|}{ Performance measures } \\
\hline One indicator & 24 & 6 & 10 & 8 & 10 & 8 & 6 & 5 & 7 & 12 \\
\hline Two indicators & 5 & - & 4 & 1 & 4 & 1 & - & - & 2 & 3 \\
\hline Three or more indicators & 7 & - & 5 & 2 & 3 & 3 & 1 & - & 3 & 4 \\
\hline
\end{tabular}




\begin{tabular}{|c|c|c|c|c|c|c|c|c|c|c|}
\hline \multirow[b]{3}{*}{$\begin{array}{l}\text { Methodology } \\
\text { characteristics }\end{array}$} & \multicolumn{10}{|c|}{$\underline{\text { Study characteristics }}$} \\
\hline & \multirow[b]{2}{*}{$\begin{array}{l}\text { Total } \\
(n=36)\end{array}$} & \multicolumn{3}{|c|}{ Time of study } & \multicolumn{3}{|c|}{ Geographic focus } & \multicolumn{3}{|c|}{ Product type } \\
\hline & & $\begin{array}{l}1970 \mathrm{~s} \\
(n=6)\end{array}$ & $\begin{array}{l}1980 \mathrm{~s} \\
(n=19)\end{array}$ & $\begin{array}{l}1990 \mathrm{~s} \\
(n=11)\end{array}$ & $\begin{array}{l}\text { America } \\
(n=17)\end{array}$ & $\begin{array}{l}\text { Europe } \\
(n=12)\end{array}$ & $\begin{array}{l}\text { Other } \\
(n=7)\end{array}$ & $\begin{array}{l}\text { Consumer } \\
(n=5)\end{array}$ & $\begin{array}{l}\text { Industrial } \\
(n=12)\end{array}$ & $\begin{array}{l}\text { Both } \\
(n=19)\end{array}$ \\
\hline \multicolumn{11}{|c|}{ Statistical analysis ${ }^{\mathrm{a}}$} \\
\hline Descriptive & 6 & 2 & 2 & 2 & 1 & 3 & 2 & 1 & 1 & 4 \\
\hline Uni/Bivariate & 14 & 2 & 9 & 3 & 9 & 4 & 1 & 2 & 5 & 7 \\
\hline Multivariate & 19 & 3 & 10 & 6 & 9 & 6 & 4 & 2 & 6 & 11 \\
\hline
\end{tabular}

${ }^{\text {a }}$ It is possible for a study to cover more than one alternative.

N. A. = not available.

tive statistics were used both to determine the frequency of various methodological parameters, as well as to identify variations due to the time of study, geographic focus, and product type. The Mosteller and Bush (1954) method of "adding weighted $Z$-values" was then applied to determine the associative strength of each marketing strategy factor with its corresponding export performance measure. ${ }^{8}$ This process converted $p$-values for each variable into $Z$-values; subsequently, corresponding degrees of freedom were estimated from the sample size used in each study. As with the methodological parameters, meta-analytical results were also tested vis a vis the time of study, geographic focus, and product type.

\section{Characteristics of studies reviewed}

As empirical findings tend to be idiosyncratic in relation to the research method employed, it is important to examine methodological aspects of the studies included in this metaanalytical exercise. The research methodologies used in the studies were evaluated along five dimensions. These refer to (a) fieldwork characteristics (i.e., time of study, geographic focus, and product type), (b) sampling and data collection (i.e., unit of analysis, company size, sampling design, sample size, response rate, nonresponse bias, data collection methods, and key informants), (c) operationalization of export performance, (d) marketing strategy variables investigated, and (e) analysis (i.e., statistical techniques). Key

\footnotetext{
${ }^{8}$ The Mosteller and Bush's (1954) method is a meta-analysis technique used in combining two or more studies that test essentially the same directional hypothesis (Hedges and Olkin, 1985; Rosenthal, 1986). This method adds the products resulting from the multiplication of sample sizes with $Z$-values, and then divides them by the square root of the squared sample sizes. It is perhaps the most reliable among the techniques for combining probabilities (e.g., adding logs, adding probabilities, adding $t$ 's, or adding $Z$-values) because it permits the investigator to weigh each study by its sample size (or by its degrees of freedom). In addition, this technique has three major advantages: (a) it can be used with any number of studies; (b) it takes into account the positive or negative association between dependent and independent variables; and (c) it is routinely applicable (Rosenthal, 1986).
}

methodological aspects of the studies reviewed are summarized in Table 1 and examined in some detail subsequently.

\subsection{Fieldwork characteristics}

Attempts to investigate the influence of marketing strategy on export performance began in the early 1960s with the pioneering work of Tookey (1964), who surveyed British exporters. Since then, there has been a slow but steady increase in the number of empirical inquiries focusing on the subject, reaching a peak of 19 studies during the 1980s. Based on the incidence of studies conducted during the first half of the 1990s, it appears that this growth trend will continue. The growing liberalization, integration, and competition in world economies (Douglas and Craig, 1995) and subsequent performance difficulties encountered by exporters may explain the growth in scholarly research in this area. With the exception of two studies (i.e., McGuinness and Little, 1981; Bilkey, 1985), the literature under review employed crosssectional, static research designs.

In terms of geographic focus, the majority of studies were conducted in North America (19), followed by Europe (12), and other parts of the world (7). Although interest in the subject appeared and developed almost simultaneously in these regions, particular concern and critical need were expressed by American researchers, probably due to the chronic trade deficits that plagued the US economy during most of the period under investigation. Two important observations can be made with respect to the geographic coverage of the studies under review. First, only two studies used a cross-national database (McDougal and Stening, 1975; Dominguez and Sequeira, 1993). Second, some studies focusing on relatively large national markets, such as the US, the UK, or Canada, confined their analysis to certain regions (McGuinness and Little, 1981; Beamish and Munro, 1986; De Luz, 1993), states (Bilkey, 1982; Cavusgil and Zou, 1994), or even counties (Tookey, 1964; Evangelista, 1994).

Twelve studies concentrated exclusively on industrial goods, five focused on consumer products, while the remainder incorporated both product types. As might be 
expected, the sample firms included in the studies reviewed manufactured diverse products ranging from food, beverages, and clothing to electronics, semiconductors, and machine tools. Further, a quarter of the studies confined their scope to up to three industries, another 10 covered four to seven industrial sectors, and only a few studies reported wider industrial coverage.

\subsection{Sampling and data collection}

In the overwhelming majority of studies, the unit of analysis was the business firm selling part or all of its products abroad. In these cases, export performance was examined within the context of the company's overall business efforts in international markets. In five studies, conducted mainly in North America, the unit of analysis was the export venture level. This unit of analysis is rationalized on the basis that a firm has a portfolio of foreign business relationships, each of which might have a different effect on export performance (Madsen, 1989; Cavusgil and Zou, 1994). In terms of company size, the emphasis was on small- and medium-sized firms, which is consistent with these firms' greater number and potentially more important roles in exporting (Axinn, 1994). However, approximately two-thirds of the studies also incorporated large companies in their investigations, mainly for the purpose of detecting differences in export performance attributed to variations in firm size.

Probability sampling designs, used in 20 studies, were the most popular methods for sample selection (see Table 1); nonprobability sampling techniques, generally convenience samples, were used less often. Sample sizes ranged from 48 to 690 , with two-thirds of the studies examining fewer than 150 firms. Four observations can be made in this regard. First, studies conducted in the 1980s used relatively small sample sizes, whereas those appearing in the 1990s tended to utilize larger samples. Second, small samples are most common among European studies. Third, larger sampling frames are associated with cross-sectional studies that seek a broader coverage. Finally, small samples were more evident among studies employing nonprobability designs and large samples were commonly associated with the use of probability sampling methods.

Response rates ranged from $7 \%$ to $83 \%$, with about one-half of the studies obtaining responses from more than $30 \%$ of the targeted companies. European studies reported higher response rates than studies conducted in North America. Nonresponse tests were carried out by approximately one-third of the studies reviewed, a common pattern in recent research and in US and Canadian studies. Mail survey was the principal data collection method (34 studies), followed by personal and telephone interviews. In most cases, personal and telephone interviews were used to supplement information obtained from mail questionnaires. Approximately one-half of the studies disclosed their key informants. Export officers constituted the major source of data followed by marketing managers and CEOs or presidents.

\subsection{Operationalization of export performance}

Performance assessment is a complex issue for numerous reasons. Because firms typically do not report the financial details of their exporting activities, it is difficult to access readily available and valid archival data. Moreover, financial figures are subject to national and local accounting standards, as well as to managerial perceptions/satisfaction with a given level of performance, which may or may not converge in a multiple industry or cross-national setting. Specification and assessment of costs associated with exported products are also problematic, as such costs are inherently related to how a firm views exporting activities. For example, allocation of overheads to export transactions can be arbitrary if exporting is merely an occasional activity, and/or if the firm generally recovers its fixed costs from domestic operations (i.e., engages in marginal pricing for competitive and/or export profit level determination); here, export profit figures might be artificially high. Alternatively, firms that consider exporting a risky and expensive business might report unrealistically low export performance figures. Thus, both objective and subject export performance data are idiosyncratic to firms' views of their exporting activities and overhead allocation approaches (i.e., export profit margin measures). In contrast, corporate performance data must comply with prevailing accounting standards, which are audited and reported in accordance with legal requirements and established practices.

The majority of performance measures in the studies under review are subjective or perceptual evaluations, made by the manager generally responsible for export operations, and therefore subject to several sources of bias. First, company officials may be reluctant to disclose confidential information to outsiders, particularly regarding a single segment of their business. Second, the majority of exporters are small- to medium-sized private firms, some of which may lack appropriate export accounting mechanisms for reporting purposes. Third, in general, managers are under no obligation to publicly disclose export sales or allied performance data.

However, there is evidence in the strategic management literature that points to the general reliability of subject, selfreported performance data (Dess and Robinson, 1984; Venkatraman and Ramanujam, 1986, 1987). This position is based on the hypothesis that since the unit of analysis is the firm or SBU responding executives have detailed knowledge of their export performance and use this information to develop or fine-tune their export marketing strategies. Although financial data have the appearance of greater accuracy, these performance measures are also potentially biased due to their limited time horizon, variance in the level of data aggregation across organizations, and departures from the actual purpose of such measures (McGuire et al., 1986; Kirpalani and Balcome, 1987). Thus, a variety of 
financial as well as nonfinancial measures have been used to assess export performance.

As stated earlier, 12 dimensions of export performance, classified into eight groups, were identified: export proportion of sales or export intensity (16), export sales growth (8), export profit level (7), export sales volume (5), export market share (4), and export profit contribution (3). Each of the remaining export performance measures appeared only once and were merged under the "other" performance measure category. ${ }^{9}$ Composite export performance measures were employed by more than one-fifth of the studies, which often combined up to four of these variables. Two-thirds of the studies examined the influence of marketing strategy variables on a single export performance measure, five studies focused on two measures, while the remainder, i.e., those adopting the combined approach, used three or more measures. ${ }^{10}$ On average, 1.5 export performance measures were used by the studies under review.

\subsection{Marketing strategy variables}

While a total of 38 different marketing strategy variables were examined by the studies under investigation, 32 appeared in at least three studies. ${ }^{11}$ For analytical purposes, these variables have been classified into five groups: targeting (3), product (10), price (6), distribution (7), and promotion (6). One-third of the studies reviewed included up to three marketing strategy variables, 14 studies employed four to six measures, while the remainder used a greater number of variables. On average, 4.3 variables were utilized by the studies under review, indicating a relatively weak operationalization of the marketing strategy construct. Product is the element of marketing strategy that has attracted the most research attention (particularly product adaptation, product advantage, and product quality); following this are distribution (distribution adaptation, channel type, and dealer support) and pricing (price adaptation, pricing strategy, and pricing method).

\footnotetext{
${ }^{9}$ The other six measures of export performance were return on investment, export satisfaction, perceived success, perceived export growth, perceived profitability, and perceived market share.

10 The use of a wide variety of export performance measures creates some difficulty in analyzing and interpreting the results of the metaanalysis. To some extent, this creates presentation problems as noted by one anonymous reviewer, because of the need to cover the full range of results referring to the various alternative associations between strategy variables and performance measures, thus leading to dense textual treatment. Nonetheless, this approach is both inevitable and essential. As shown in Table 2, despite the fact that the vast majority of the marketing variables were significantly associated with overall export performance, the same variables were related significantly to certain individual performance measures only. It is important that such detailed evidence is provided by this assessment exercise to be considered in future research efforts.

11 The remaining six marketing strategy variables that appeared on a less frequent basis and, therefore, are not included in the meta-analysis were entry mode, product features, transportation costs, freight costs, documentation, and publicity.
}

\subsection{Analysis}

Statistical methods used to assess the relationship between export marketing strategy and export performance were often advanced. Only one-sixth of the studies used descriptive statistics, usually taking the form of frequencies or mean scores. Another 14 studies employed univariate (mainly chi-square) or bivariate (mainly Pearson correlation, ANOVA, and simple regression) statistics. The majority of studies, however, utilized multivariate analytical techniques such as cluster analysis, multiple discriminant analysis, and multiple regression analysis. Due to the heterogeneity of the statistical tools used in extant research, it was necessary that individual study results be transformed into a common unit, i.e., the $p$-value. ${ }^{12}$

\section{Findings and analysis}

The $p$-values derived for each of the 32 export marketing strategy variables were subsequently combined using the method of "adding weighted $Z$-values." 13 In this context, three levels of analyses were pursued: (a) the influence of marketing strategy variables on overall export performance; (b) the effect of marketing strategy variables on specific measures of export performance; and (c) variations of marketing strategy effects on overall export performance due to time of study, geographic focus, and product type. Table 2 presents the results with respect to the first two levels of analyses, whereas findings related to the effects of the studies' characteristics on the export strategy-performance relationship are shown in Table 3 . The results are expressed in terms of significance levels, followed by a discussion of export targeting, product, pricing, distribution, and promotion aspects of the export marketing strategyperformance relationship.

\subsection{Export targeting}

Export targeting involves the number and types of export markets (i.e., countries) a firm may select, as well as its segmentation activities within each export market (cf. Albaum et al., 1997). Segmentation is central to the firm's marketing strategy development and implementation. However, in the studies reviewed, market segmentation takes a different role than that normally employed in the domestic context. In general, two export targeting aspects were identified in the studies under review: export expansion

\footnotetext{
12 To verify the validity of the results, Fisher's method of adding logs was also used, revealing similar findings (Rosenthal, 1986; Wolf, 1986).

${ }^{13}$ Some studies did not disclose the exact $p$-values associated with the influence of specific marketing strategy variables on export performance. These values had to be inferred from the critical value set by the authors of these studies.
} 
Table 2

Marketing strategy-export performance relationship ( $p$-values)

\begin{tabular}{|c|c|c|c|c|c|c|c|c|c|}
\hline \multirow[b]{2}{*}{ Export strategy area } & \multicolumn{9}{|c|}{ Export performance indicator } \\
\hline & $\begin{array}{l}\text { Overall } \\
\text { export } \\
\text { performance }\end{array}$ & $\begin{array}{l}\text { Export } \\
\text { sales } \\
\text { volume } \\
\end{array}$ & $\begin{array}{l}\text { Export } \\
\text { sales } \\
\text { growth }\end{array}$ & $\begin{array}{l}\text { Export } \\
\text { sales } \\
\text { intensity }\end{array}$ & $\begin{array}{l}\text { Export } \\
\text { profits } \\
\text { level }\end{array}$ & $\begin{array}{l}\text { Export } \\
\text { profit } \\
\text { contribution } \\
\end{array}$ & $\begin{array}{l}\text { Export } \\
\text { market } \\
\text { share }\end{array}$ & $\begin{array}{l}\text { Other } \\
\text { performance } \\
\text { measure }\end{array}$ & $\begin{array}{l}\text { Composite } \\
\text { performance } \\
\text { measure }\end{array}$ \\
\hline \multicolumn{10}{|l|}{ Targeting } \\
\hline Market concentration & 0.000 & 0.009 & 0.013 & 0.000 & 0.057 & 0.100 & 0.499 & - & 0.100 \\
\hline Market spreading & 0.000 & 0.100 & 0.025 & 0.000 & 0.063 & 0.100 & 0.499 & - & 0.100 \\
\hline Market segmentation & 0.000 & 0.100 & 0.000 & 0.005 & 0.024 & - & - & - & - \\
\hline \multicolumn{10}{|l|}{ Product } \\
\hline Design & 0.027 & - & - & - & - & - & - & - & 0.027 \\
\hline Quality & 0.000 & - & - & 0.049 & 0.049 & 0.049 & 0.099 & - & 0.059 \\
\hline Branding & 0.018 & 0.100 & 0.200 & 0.033 & 0.025 & - & - & 0.205 & 0.200 \\
\hline Packaging/labeling & 0.100 & 0.100 & - & 0.100 & 0.100 & - & - & - & - \\
\hline Customer service & 0.000 & 0.100 & 0.200 & 0.000 & 0.002 & 0.049 & - & - & 0.002 \\
\hline Warranty & 0.036 & - & - & 0.099 & - & - & - & - & 0.100 \\
\hline Product advantage & 0.000 & 0.001 & 0.005 & 0.007 & 0.001 & 0.100 & 0.009 & - & 0.163 \\
\hline New/unique product & 0.000 & - & 0.200 & 0.002 & 0.013 & 0.038 & - & - & - \\
\hline Product/brand mix & 0.000 & 0.100 & 0.200 & - & - & 0.100 & - & - & 0.100 \\
\hline Product adaptation & 0.000 & 0.004 & 0.000 & 0.000 & 0.122 & 0.100 & 0.158 & 0.325 & 0.007 \\
\hline \multicolumn{10}{|l|}{ Price } \\
\hline Pricing method & 0.000 & 0.100 & 0.200 & 0.015 & 0.019 & - & - & 0.094 & - \\
\hline Pricing strategy & 0.000 & 0.100 & 0.025 & 0.049 & 0.053 & 0.100 & - & 0.001 & 0.024 \\
\hline Sales terms & 0.050 & - & - & 0.049 & - & - & - & 0.091 & - \\
\hline Credit policy & 0.001 & - & 0.200 & 0.100 & 0.031 & - & - & - & 0.024 \\
\hline Currency strategy & 0.251 & 0.100 & - & 0.022 & 0.100 & - & - & 0.013 & 0.251 \\
\hline Price adaptation & 0.000 & 0.100 & 0.012 & 0.001 & 0.031 & - & - & - & - \\
\hline \multicolumn{10}{|l|}{ Distribution } \\
\hline Distributors/agents & 0.065 & - & - & 0.100 & - & 0.999 & - & 0.027 & 0.014 \\
\hline Sales representatives/office & 0.051 & - & - & 0.007 & - & 0.999 & - & 0.007 & - \\
\hline Merchants & 0.144 & - & 0.047 & 0.200 & - & 0.999 & - & 0.002 & - \\
\hline Direct buying & 0.438 & - & 0.200 & 0.018 & 0.099 & 0.909 & 0.100 & - & - \\
\hline Dealer support & 0.000 & 0.009 & 0.016 & 0.000 & 0.005 & 0.747 & - & 0.794 & 0.005 \\
\hline Delivery time & 0.001 & 0.100 & 0.036 & 0.030 & 0.051 & - & - & - & 0.014 \\
\hline Distribution adaptation & 0.000 & - & 0.200 & 0.000 & 0.017 & 0.100 & 0.099 & - & 0.099 \\
\hline \multicolumn{10}{|l|}{ Promotion } \\
\hline Advertising & 0.000 & - & 0.200 & 0.000 & 0.051 & - & 0.099 & 0.008 & 0.001 \\
\hline Sales promotion & 0.000 & 0.100 & - & 0.016 & 0.100 & - & - & 0.019 & 0.000 \\
\hline Personal selling & 0.000 & - & - & - & - & - & - & 0.029 & 0.001 \\
\hline Trade fairs & 0.004 & - & - & 0.049 & - & - & - & - & 0.010 \\
\hline Personal visits & 0.001 & - & - & 0.000 & - & 0.100 & - & 0.332 & 0.049 \\
\hline Promotion adaptation & 0.000 & 0.100 & 0.021 & 0.002 & - & 0.361 & - & 0.197 & - \\
\hline
\end{tabular}

and market segmentation. For analytical reasons, export expansion was further split into market concentration and market spreading in reference to the highly contentious issue of whether the company should concentrate its efforts on a few foreign markets or attempt to export to as many international markets as possible (Piercy, 1981a; Katsikeas and Leonidou, 1996).

The results of the meta-analysis revealed that use of a market concentration strategy was related positively to overall export performance $(p<0.001)$. In fact, this was more evident in studies conducted during the last two decades, as well as in those with a cross-sectional or industrial goods focus. However, examination of this variable in relation to individual export performance measures unveiled mixed results. Whereas market concentration exhibited a significant positive influence on sales-based performance indicators (export sales volume, growth, and intensity), weak associations were observed for the remaining measures, particularly export market share. To some extent, these findings support the rationale behind the use of this strategy, which depends on superior market and distribution knowledge, greater opportunity to exploit nonprice competitive advantage, and sales increase through better quality of selling efforts (BETRO, 1976). However, results 
Table 3

Marketing strategy-performance relationship by study characteristics ( $p$-values)

\begin{tabular}{|c|c|c|c|c|c|c|c|c|c|}
\hline \multirow[b]{3}{*}{ Export strategy areas } & \multicolumn{9}{|c|}{ Study characteristics } \\
\hline & \multicolumn{3}{|c|}{ Time of study } & \multicolumn{3}{|c|}{ Geographic focus } & \multicolumn{3}{|c|}{ Product type } \\
\hline & $1970 \mathrm{~s}$ & $1980 \mathrm{~s}$ & $1990 \mathrm{~s}$ & America & Europe & Other & Consumer & Industrial & Both \\
\hline \multicolumn{10}{|l|}{ Targeting } \\
\hline Market concentration & 0.019 & 0.000 & 0.004 & 0.000 & 0.010 & 0.000 & 0.049 & 0.000 & 0.000 \\
\hline Market spreading & - & 0.000 & 0.004 & 0.003 & - & 0.002 & - & 0.003 & 0.001 \\
\hline Market segmentation & - & 0.000 & - & 0.000 & - & 0.186 & - & 0.000 & - \\
\hline \multicolumn{10}{|l|}{ Product } \\
\hline Design & - & 0.049 & 0.100 & - & 0.027 & - & - & 0.100 & 0.049 \\
\hline Quality & 0.049 & 0.001 & 0.100 & 0.099 & 0.001 & 0.100 & - & 0.099 & 0.001 \\
\hline Branding & 0.205 & 0.001 & 0.200 & 0.207 & - & 0.013 & - & 0.018 & - \\
\hline Packaging/labeling & - & 0.100 & - & - & - & 0.100 & - & 0.100 & - \\
\hline Customer service & 0.049 & 0.000 & 0.001 & 0.000 & 0.002 & 0.006 & - & 0.000 & 0.000 \\
\hline Warranty & - & 0.099 & 0.100 & 0.099 & 0.100 & - & - & - & 0.036 \\
\hline Product advantage & - & 0.000 & 0.033 & 0.000 & 0.000 & 0.274 & - & 0.016 & 0.000 \\
\hline New/unique product & - & 0.000 & 0.019 & 0.007 & 0.000 & - & - & 0.011 & 0.000 \\
\hline Product/brand mix & - & 0.000 & 0.007 & 0.000 & 0.041 & 0.026 & 0.100 & 0.003 & 0.001 \\
\hline Product adaptation & 0.009 & 0.000 & 0.000 & 0.000 & 0.001 & 0.001 & 0.000 & 0.000 & 0.084 \\
\hline \multicolumn{10}{|l|}{ Price } \\
\hline Pricing method & 0.100 & 0.001 & - & 0.008 & - & 0.005 & - & 0.001 & 0.100 \\
\hline Pricing strategy & - & 0.000 & 0.017 & 0.001 & 0.000 & 0.117 & 0.100 & 0.001 & 0.000 \\
\hline Sales terms & - & 0.050 & - & 0.091 & 0.049 & - & - & 0.050 & - \\
\hline Credit policy & - & 0.011 & 0.024 & 0.011 & 0.100 & 0.049 & - & 0.011 & 0.024 \\
\hline Currency strategy & 0.084 & 0.337 & - & 0.987 & 0.019 & 0.013 & 0.084 & 0.337 & - \\
\hline Price adaptation & - & 0.004 & 0.004 & 0.000 & 0.004 & 0.344 & - & 0.004 & 0.004 \\
\hline \multicolumn{10}{|l|}{ Distribution } \\
\hline Distributors/agents & 0.994 & 0.007 & 0.014 & 0.999 & 0.002 & 0.014 & - & - & 0.065 \\
\hline Sales representatives/office & 0.479 & 0.003 & - & 0.365 & 0.100 & 0.019 & - & 0.011 & 0.011 \\
\hline Merchants & 0.909 & 0.000 & 0.200 & 0.285 & 0.047 & 0.200 & - & 0.001 & 0.983 \\
\hline Direct buying & 0.909 & 0.034 & 0.014 & 0.479 & - & 0.200 & - & 0.200 & 0.479 \\
\hline Dealer support & 0.909 & 0.000 & 0.000 & 0.013 & 0.000 & - & 0.001 & 0.000 & 0.000 \\
\hline Delivery time & - & 0.015 & 0.002 & 0.015 & 0.003 & 0.050 & - & 0.008 & 0.003 \\
\hline Distribution adaptation & 0.037 & 0.000 & 0.035 & 0.000 & 0.035 & 0.200 & 0.035 & 0.000 & 0.003 \\
\hline \multicolumn{10}{|l|}{ Promotion } \\
\hline Advertising & 0.049 & 0.000 & 0.001 & 0.000 & 0.000 & - & 0.001 & 0.000 & 0.000 \\
\hline Sales promotion & - & 0.000 & 0.001 & 0.019 & 0.000 & 0.019 & 0.001 & 0.003 & 0.009 \\
\hline Personal selling & - & 0.000 & 0.001 & 0.029 & 0.001 & - & 0.001 & - & 0.029 \\
\hline Trade fairs & - & 0.029 & 0.010 & - & 0.004 & - & - & - & 0.004 \\
\hline Personal visits & 0.002 & 0.075 & 0.019 & 0.036 & 0.004 & 0.019 & - & 0.213 & 0.000 \\
\hline Promotion adaptation & - & 0.000 & 0.003 & 0.001 & 0.004 & - & - & 0.000 & 0.003 \\
\hline
\end{tabular}

do not indicate that market concentration can lead to higher market shares. ${ }^{14}$

In a similar vein, market spreading also demonstrated a strong impact on general export performance levels, irrespective of time, place, or product type. With the exception of export sales volume, the pattern of association of market spreading with individual export performance measures was similar to that of market concentration. Specifically, of the eight measures examined, market spreading strategy was

\footnotetext{
${ }^{14}$ In general, the use of export market share as a performance measure poses several problems that are discussed in Section 4.
}

related positively to export proportion of sales $(p<0.001)$ and export sales growth $(p<0.005)$ only. These findings are in direct contrast to some of the benefits cited by proponents of this strategy, particularly those referring to increased profitability. Further, both export market expansion strategies exhibit a weak relationship with composite measures of export performance.

Within the exporting context, market segmentation has been described as a dual process wherein homogeneous groups of countries are first defined and identified according to common environmental characteristics, followed by further division of these national markets into segments of customers that differ in terms of response to marketing 
strategies (Keegan, 1995). Market segmentation has received less attention than market expansion strategies (e.g., Cooper and Kleinschmidt, 1985; Namiki, 1994), and those studies focusing on segmentation were concerned primarily with industrial products and conducted in the US during the 1980s. Their findings support the presence of a positive relationship between segmenting international markets and export performance $(p<0.001)$, particularly in terms of export sales growth, intensity, and profit level.

\subsection{Product}

The influence on export performance of various product dimensions, including actual and augmented product factors, has been given considerable attention (e.g., McGuinness and Little, 1981; Kaynak and Kuan, 1993; Cavusgil and Zou, 1994). A few studies, which all employed composite export performance measures, focused on product design. This marketing mix element has been viewed as conducive to successful exporting in that it can serve as a means of differentiation for competitors' offerings and influence overseas customer attitudes toward a firm's product (Albaum et al., 1997). Overall, product design and style were shown to have a significant positive effect on performance $(p<0.05)$. However, product design in the industrial market context showed no correlation with performance. In contrast, the relationship between product quality and export performance was widely researched and positively associated $(p<0.01)$. Two observations regarding product quality are noteworthy. First, the positive influence of product quality on export performance was stressed more in older studies and those conducted in Europe. Second, the data indicated a weak association between product quality and export market share or composite measures of export performance.

The relationship between branding and export performance was narrow in scope, but significant, ${ }^{15}$ varying according to the time of study and its geographic focus. Only research conducted in the 1980 s, on industrial products, and which was located outside of the US and Europe, revealed significant links between branding and performance. Branding variables were found to be positively related to overall export performance, as well as to export

\footnotetext{
15 Branding entails decisions relating to the name, sign, symbol, design, or a combination of these decision areas that are intended to identify and differentiate the exporter's product in international markets. The studies examining this marketing strategy variable (e.g., Namiki, 1988, 1994; Kaynak and Kuan, 1993) treated branding in a general fashion without reference to a specific dimension (e.g., brand sponsorship, brand strategy, and brand adaptation). As a result, when examining the association between branding and export performance, it is difficult to specify which aspect of branding influences performance. The lack of detailed analysis on branding, as well as other dimensions of export marketing strategy, is a problem inherent in the studies under review, which is inevitably reflected in the results of this meta-analysis.
}

intensity and profit level $(p<0.05)$. Packaging and labeling were the only product variables that had no effect on composite or individual (i.e., export intensity, sales volume, and profitability) export performance measures. These two variables were examined only for industrial products (whose purchases are typically policy-driven and more rational than emotional). Further, customer requirements and regulations governing packaging and labeling can vary significantly among markets, and these factors can easily explain the lack of relationship. Surprisingly, the influence of these variables in relation to consumer products has not been investigated. Although it is reasonable to expect a positive relationship, it represents a research gap to be addressed.

Customer service (i.e., provisions for pre- and aftersales services) has been cited as a critical success factor in international markets. International customers are particularly concerned over the exporter's ability to offer the necessary services (Terpstra and Sarathy, 1997), and the results of the meta-analysis supported this assertion $(p<0.001)$. Further, this variable revealed a significant correlation with export performance irrespective of time, geographic area, and products studied. Notably, customer service was not significantly related to export sales growth and produced only moderate results $(p<0.1)$ with export volume.

The provision of a warranty has been postulated to augment the value of the product exported, since this can offset foreign customers' reservations regarding product performance and reduce their risk perceptions pertaining to the purchase of such goods (Terpstra and Sarathy, 1997). This element is particularly important when a firm enters a new overseas market or exports to geographically distant markets. While available empirical findings confirmed a positive relationship of this variable with export performance ( $p<0.05$ ), results should be interpreted cautiously as only a few studies examined this association.

Product-related advantages, derived from such superior attributes as luxury, prestige, and quality, have been the focus of substantial research. Results indicated that, with the exception of export profit contribution and composite measures, product-related advantages were positively associated with all export performance measures $(p<0.05)$. Because product-related advantages cannot easily be copied by competitors, this approach can potentially lead to export positional advantage, development, and success (Beamish and Munro, 1986). Closely related to product advantages are products with unique qualities, referred to in the literature as a major export stimulus (Johnston and Czinkota, 1982; Tesar and Tarleton, 1982; Kaynak and Kothari, 1984). Export product uniqueness has also been well-researched, and results indicated that it significantly influences export performance $(p<0.001)$, particularly in the case of export proportion of sales.

The firm's ability to offer a complete product or brand mix in export markets was hypothesized to be positively correlated with export performance for two reasons: (a) it 
provides an opportunity to increase sales by serving more customer segments and (b) marketing, administrative, and other exporting costs can be spread over a number of products (Beamish and Munro, 1986). However, the export product or brand mix is usually of a narrower range than that offered domestically, due to financial constraints and operational difficulties associated with overseas business activities (Albaum et al., 1997). The meta-analysis results revealed a significant affirmative relationship between this element and overall export performance $(p<0.001)$, whereas individual performance measures generally demonstrated weaker associations.

The link between product adaptation and export performance is the most widely researched issue in the extant literature, and almost one-half of the studies we reviewed examined this relationship. Product adaptation is defined in terms of the degree to which the firm's actual and augmented product elements are adapted for export markets to accommodate differences in environmental forces, consumer behavior, usage patterns, and competitive situations. Three benefits can be derived from this strategy. First, it reflects a customer-orientation posture because the exporter systematically evaluates buyer behavior and host market characteristics (Douglas and Wind, 1987). Second, it can lead to greater profitability, as a better product-market match can result in greater customer satisfaction, which can give greater pricing freedom vis a vis competitors. Third, pressures to meet specific host market requirements often demand creative and innovative thinking, which may result in additional products for a firm's domestic, as well as overseas markets (McGuinness and Little, 1981; Czinkota and Ronkainen, 1998). Thus, it is not surprising that product adaptation was correlated with superior export performance $(p<0.001)$. As shown in Table 3, this conclusion is valid across all time frames and geographic contexts. However, a closer examination reveals that significant results were found only in studies using export sales-based performance measures.

\subsection{Pricing}

Six pricing-related decision areas were examined for their potential influence on a firm's export performance: pricing method, pricing strategy, sales terms, credit policy, currency strategy, and price adaptation. Pricing method was confined to the use of a market-based pricing approach, whereby the firm sets export prices according to customer demand and competitive practices. The adoption of such an approach ensures responsiveness to changes in overseas market conditions, competitive situations, and environmental forces, increasing the likelihood of export development and success (Christensen et al., 1987). However, the metaanalysis results indicated that this argument is valid only to the extent that success is measured in terms of export proportion of sales and profit level $(p<0.05)$. The "costplus" pricing method, on the other hand, received scant empirical attention, possibly due to the focus on manufacturing firms of the studies reviewed. ${ }^{16}$

Research on pricing strategy was also narrowly defined, in the sense that it focused largely on the effect of setting low prices. By employing such an approach, exporters aim to penetrate export markets by attracting a large number of foreign customers and winning a large market share; this in turn may create a favorable impact on the achievement of scale economics (Albaum et al., 1997). Our study indicated that the adoption of a price penetration strategy was positively associated with all aspects of performance $(p<0.05)$, except those relating to profitability. By contrast, the role that the pursuit of a prestige pricing approach plays in influencing export performance was examined in only one study, which reported a positive relationship of this variable with export intensity (Amine and Cavusgil, 1986).

Sales terms are an important factor in international business because they detail the contractual responsibilities in export transactions. They can also act as a powerful competitive tool, particularly if the price quotation minimizes the liabilities and responsibilities of international customers (Koh and Robicheaux, 1988). However, sales terms were not found to influence export performance in the studies that examined this variable. A competitive credit policy was hypothesized by several studies to be conducive to successful exporting because it can enhance profits by generating a larger and better satisfied customer base (cf. Evangelista, 1994). The meta-analysis confirmed the positive relationship between credit policy and profit-based export performance measures $(p<0.01)$, while export intensity and growth indicators were not shown to be associated with the firm's export credit policy.

The currency strategy pursued by the firm in export transactions, i.e., whether products are priced in the exporter's home currency, its customer's currency, or a third currency, has attracted limited research interest. In most instances, importers prefer quotations in their own currency for two major reasons. First, host market pricing avoids the foreign exchange risk inherently associated with the depreciation of the importer's currency (Samiee and Anckar, 1998) and, second, this pricing approach makes it easier to compare offers from various foreign and national suppliers (Terpstra and Sarathy, 1997). Available findings do not support the contention that the use of a foreign currency can have a positive financial effect on export performance. However, currency strategy was found to enhance export intensity as well as certain other performance measures denoting involvement in export markets. These results are consistent with Piercy (1981b) and Samiee and Anckar (1998), who concluded that foreign

\footnotetext{
${ }^{16}$ Although cost considerations are always important in setting final prices, "cost-plus" pricing tends to be more common among channel intermediaries whose product purchase costs are generally better defined, than is the case in manufacturing firms.
} 
currencies were used much more often by active exporters (compared to reactive exporters).

The effect of price adjustment on export performance has been widely researched. Export prices may be adjusted for a number of reasons: economic, political-legal, price controls, and other environmental forces; marketing, distribution, and transportation costs; market structures and demand; tariffs, taxes, and other financial trade barriers; pricing practices of competitors; and costs and margins of distribution channels. This diversity of foreign market pricing determinants makes price adaptation necessary for firms to survive and remain competitive in host markets (Louter et al., 1991). Our results confirmed this, showing a strong positive link between price adjustment and both overall and individual export performance measures $(p<0.001)$, with the exception of export sales volume.

\subsection{Distribution}

As shown in Table 2, weak results were obtained in studies that examined the relationship between export channel intermediary type and overall export performance. The meta-analysis also revealed mixed results in the relationships of individual performance measures with particular export distribution modes. For instance, the use of an export sales representative/office and direct buying were found to be related positively to export sales intensity $(p<0.05)$, while the adoption of overseas distributors/ agents and merchants showed weak associations with this performance measure. These findings imply that the appropriateness of a particular distribution channel is not static; rather, it depends largely on variable foreign market conditions, such as economic situation, distribution structure, and competitive practices.

The exporting firm's ongoing and sustainable dealer support has been hypothesized to lead to better export performance through the development of productive and long-lasting business relationships (Cavusgil and Zou, 1994). Exporters can use various ways of supporting their dealers, including business counseling, market research assistance, sales force training, missionary selling, cooperative advertising, and financing (Czinkota and Ronkainen, 1998). Our results indicated dealer support to be positively correlated with all export performance measures, apart from export profit contribution and "other" performance indicators.

Similarly, the role which delivery time plays in influencing the export performance of the firm is a commonly researched issue. Efficiency in the delivery time of the products exported constitutes a key overseas supplier selection criterion used by importing firms, as it affects competitiveness and success in the market in which these firms operate (Piercy et al., 1997). Our results exhibited a positive relationship with export performance $(p<0.01)$, independent of study characteristics. Significant findings were also observed when delivery time was related to export sales volume, export proportion of sales, and certain composite performance measures.

Many studies researched distribution adaptation, which refers to the adjustment of the exporting firm's channel design in export markets. Such adjustments may occur in response to: (a) variations in business environments, such as legislation, economic situation, and physical conditions and (b) differences in distribution infrastructure in terms of number of middlemen, types of outlets, and channel functions (Keegan, 1995). The necessity for distribution adaptation was mirrored in the results of the meta-analysis, where a strong positive linkage with export performance was found, irrespective of the fieldwork characteristics of the studies reviewed $(p<0.001)$. In examining performance measures individually, however, positive results were observed only for export intensity and export profit level.

\subsection{Promotion}

Six promotion-related variables, i.e., advertising, sales promotion, personal selling, trade fairs, personal visits, and promotion adaptation, were examined for their effects on export performance. Advertising was the most widely researched, based on the hypothesis that with sound advertising procedures the firm can inform, remind, and/or persuade foreign customers about its products and, therefore, generate more sales. The meta-analysis results verified this view $(p<0.001)$. Advertising's positive influence was particularly evident on export sales intensity, "other performance," and composite performance measures. Similar findings were observed for sales promotion, underscoring the role of coupons, samples, premiums, and other promotional tools, particularly in countries characterized by low incomes, keen competition, and/or advertising restrictions (Cateora and Graham, 1999).

Personal selling was examined by only a small number of studies reviewed and, therefore, the results should be viewed with caution. Our analysis found that personal selling was related positively to export performance $(p<0.001)$. In particular, this marketing strategy variable can improve a firm's export performance levels in countries where there are restrictions on advertising and other promotional tools (Onkvisit and Shaw, 1997) and where the cost of maintaining and managing a sales force is low (Terpstra and Sarathy, 1997).

Participation in trade fairs has also been hypothesized to improve export performance for three reasons. First, trade fairs allow the sales potential of a specific foreign market to be tested. Second, they offer the possibility of recruiting candidates for distributorship or other collaborating initiatives in export markets. Third, they can be used for market research purposes by recording market reaction to competitive developments and making comparative evaluations of the exporter's offerings (Terpstra and Sarathy, 1997). The use of trade fairs to promote exports has been examined in several studies (e.g., Bello and Barksdale, 1986; Rosson and 
Seringhaus, 1995; Seringhaus and Rosson, 1998). However, few empirical efforts (e.g., Karafakioglu, 1986; Styles and Ambler, 1994) linked trade fairs to export performance and, thus, these results should be viewed with caution. These studies support the beneficial impact of trade fair participation on export proportion of sales and composite measures of export performance $(p<0.05)$.

Many researchers have underlined the importance of personal visits to export markets as a valuable tool for (a) gaining hands-on experience in the opportunities and problems arising in specific export markets, (b) boosting communication, personalizing relationships, and cultivating a team spirit with customers abroad, and (c) providing timely response and immediate support to the export venture's needs (Tookey, 1964; Cunningham and Spigel, 1971; BETRO, 1976; Kaynak and Kothari, 1984). The results of the meta-analysis generally supported these arguments $(p<0.001)$. It is interesting to note that the findings related to industrial goods were not indicative of this relationship, although one would expect the opposite due to the highly interdependent buyer-seller relationships established in these markets (Cateora and Graham, 1999).

Finally, an issue of special concern for export managers is whether to pursue a standardized promotion strategy across all countries, or adapt it to the specific requirements of each foreign market. Proponents of the standardization approach make several justifications for this, such as similarities in buyers' consumption patterns and the existence of international market segments. In contrast, those favoring the localization strategy cite differences in government restrictions, competitive practices, communication infrastructure, and so forth, among nations (Keegan, 1995). Our results supported the latter approach; that is, promotion adaptation exhibited a strong positive association with overall export performance, irrespective of the time, place, and products focused on in the studies reviewed. However, analysis of individual export performance measures revealed that this variable had such a strong effect only on export sales growth and export intensity, while its impact on export profit contribution was limited.

\section{Limitations}

As with any study using meta-analysis, the findings reported here should be viewed within the context of limitations endemic to such studies. First, meta-analysis procedures have been criticized for mixing results from research of different quality (Wachter, 1998) and for their bias toward the publication of studies that reject their null hypotheses (Rust et al., 1990). Second, although every effort was made to systematically and comprehensively review the export literature and select the relevant studies, literature review studies inherently risk excluding some pertinent publications. Third, certain relevant empirical studies were excluded because they failed to meet all eligibility criteria described in Section 1. Fourth, the research methods used in the studies targeted for this review were incongruent, particularly in sampling, construct operationalization, and statistical techniques. Fifth, in some cases, because detailed statistics were unavailable, the strength of association between marketing strategy variables and export performance was based on the significance levels set in the studies. Finally, some studies lacked sufficient information regarding operationalizations of key constructs, particularly export performance.

Two additional limitations pertaining to certain dependent and independent measures are imposed on the foregoing analysis by the literature reviewed. The first limitation is that the use of export market share as a performance measure is problematic, as the accuracy of an export manager's knowledge of this is questionable for several reasons.${ }^{17}$ First, accurate assessment of market share depends on external information, and this is often unavailable and potentially unreliable (Kirpalani and Balcome, 1987). Second, a firm may be selling several products, each of which may perform differently in and across export markets in which the firm is active (Cavusgil and Zou, 1994). Third, in the absence of an investigator-generated definition for market share, a responding firm may also compare itself with its domestic exporting rivals (i.e., report the firm's proportion of all exports in a given product category) rather than market share in targeted export markets. These are important conceptual and definitional issues that are generally not adequately addressed in the exporting studies reviewed. However, since export proportion of sales was the most common performance criterion, and approximately one-third of the studies reviewed employed more than one export performance measure, the use of export market share should not present an insurmountable problem in this meta-analysis.

A second literature imposed limitation is the unequal emphasis placed on the various marketing strategy variables and performance measures; some variables, such as product design and personal selling, were covered by only a few studies. Although the studies were screened for linking export performance to marketing strategy variables, their objectives and coverage of dependent and, in particular, independent variables varied from one study to another. However, the meta-analytical technique used in our study (Mosteller and Bush, 1954) both considered and addressed these variations sufficiently to mitigate the effect of this limitation.

\section{Conclusions and implications}

While this study has primarily assessed the association between export marketing strategy and performance (based

\footnotetext{
${ }^{17}$ The contribution of an anonymous reviewer regarding this issue is gratefully acknowledged.
} 
on analysis of the extant literature), it also provides some valuable insights into the general debate on the strategyperformance relationship. The strategic management literature has reported mixed results with regard to the relationship between strategy and performance (Greenley, 1986; Pearce et al., 1987). The main variables considered in the present study (i.e., export marketing strategy and export performance) occur at a lower level within the firm and are more functionally oriented. Nevertheless, the meta-analysis results reported here are consistent with those reported for a meta-analysis of the strategy-performance literature at the business unit level (Miller and Cardinal, 1994). In general, there appears to be a strong association between export marketing strategy and export performance measures.

Thus, the central conclusion of this review is that the implementation of a well-designed export marketing strategy can indeed determine export success, since the overwhelming majority of the marketing strategy variables were significantly associated with overall export performance. Market segmentation, product quality, pricing strategy, dealer support, and advertising were found to influence positively performance in export markets. These relationships give credibility to normative claims made by leading international marketing scholars. The weak marketing strategy-performance relationships observed for some marketing measures might be situation specific. A case in point is distribution mode variables, where weak results could be explained if the choice of an appropriate distribution method depends largely on the firm's stage of export development (Leonidou and Katsikeas, 1996). Further, we found that study characteristics (such as the time of study, geographic focus, and product type) have a limited impact on export performance. Nonetheless, it is noteworthy that the link between marketing strategy variables and export performance is stronger in research more recently conducted, and most evident in studies undertaken within Europe.

Despite the affirmative results observed at the overall export performance level, marketing strategy variables correlated significantly with only certain individual performance measures. The vast majority of these variables were related positively to export proportion of sales (i.e., export intensity). Furthermore, a sizeable number of positive associations were observed with respect to export sales growth and export profit level. In contrast, and with but few exceptions, marketing strategy variables were poorly connected with export market share, profit contribution, and sales volume. The lack of association between export marketing strategy and export market share and profit contribution is likely to be related to measurement difficulties. For instance, export profits are particularly difficult to measure because of the greater uncertainty associated with the cost, and hence profit margins, of products being exported.

All variables related to marketing strategy adaptation for export markets emerged as significant determinants of export success, especially when this was measured in terms of export proportion of sales. Moreover, variables incurring high costs for the exporting organization, such as personal visits, advertising, and sales promotion, exhibited stronger positive relationships with sales-focused measures of export performance as opposed to profit-oriented ones. Nonetheless, only a few marketing parameters, namely, product advantage, pricing strategy, and dealer support, significantly affected different measures of performance, underscoring their strategic importance in exporting.

These findings can assist business managers in their endeavor to formulate sound export marketing strategies and achieve success in international markets. The collective knowledge gained from extant empirical research on the subject points to the compelling need to systematically adapt the elements of the export marketing strategy to account for the idiosyncrasies of specific export markets. However, the degree of emphasis given to each marketing strategy parameter will depend on the firm's specific export marketing objectives. For example, if the objective is to improve sales performance indicators, special consideration should be given to the adaptation of marketing strategy, while higher profitability can be achieved by employing a market-led pricing strategy. Of course, the design and implementation of a coherent export marketing program is a dynamic task which requires continuous monitoring, evaluation, and revision, according to the specific conditions prevailing in export markets at a particular point in time. Concurrently, it would be unrealistic to expect firms to optimize and excel in all components of export marketing strategy, because firms often lack the necessary resources and capabilities to accomplish such a complex task. Certainly, knowledge of the critical importance of export marketing strategy variables reported in Tables 2 and 3 is a useful starting point.

\section{Future research directions}

This meta-analytical study has yielded valuable information, which future research can build upon in numerous ways. First, studies relating the full set of marketing strategy variables identified in this assessment to various facets of export performance within the context of an integrated model would be of immense value (Evangelista, 1994). Such studies should be supplemented by additional marketing strategy variables not adequately covered by extant empirical research, including foreign market selection, market positioning, and distribution logistics. Moreover, there is a need to improve export performance measurement by using more direct, composite, and objective measures. For instance, it would be useful to extract information from company financial statements which, apart from reducing the possibility of key informant bias, would enable the development of more robust performance measures, such as return on assets employed in export operations. In 
situations, where export sales and profit information is not reported, a reliance on multiple informants within each exporting firm is likely to produce more valid performance results. It is also important that the product(line)-market be employed as the level of analysis, as this approach can overcome many of the export performance measurement problems inherent in corporate-level investigations (Kirpalani and Balcome, 1987).

Second, to enhance knowledge in the field, more research should be channeled toward understanding the role of antecedent variables pertaining to managerial, organizational, and environmental elements in influencing export marketing strategy, and how such factors affect export performance. Although these variables have been directly related to export performance in a number of studies, their role in affecting marketing strategy variables has received limited attention (Cunningham and Spigel, 1971; Cooper and Kleinschmidt, 1985; Culpan, 1989; Cavusgil and Zou, 1994). For example, the product's life-cycle stage, the degree of competition in export markets, and host government restrictions on trade are likely to affect the nature of the marketing strategy elements, which in turn may impact upon export performance (Aaby and Slater, 1989).

Third, marketing strategy can comprise numerous elements with variable effects on performance. Exporting firms must optimally allocate their (scarce) resources to the appropriate subset of marketing activities if they are to achieve superior export performance. Therefore, it is useful to assess the relative importance of each marketing variable within the export marketing strategy. Concurrently, it is important to address possible multicollinearity problems since some variables may be interconnected, as in the classic case of product quality and pricing strategy (Madsen, 1987). Further, the direction of causality between marketing strategy variables and export performance measures requires particular attention, because the cross-sectional data used in this stream of research cannot account for cause-effect inferences. Longitudinal research designs or time lags to assess the same panel of firms could effectively alleviate this problem (Katsikeas et al., 1996).

Fourth, because involvement in export operations is not static, but an evolutionary process, it is imperative to examine how the stage of export development affects the export marketing strategy-performance relationship. For example, evidence suggests that firms at the initial exporting stages tend to adopt more standardized export marketing strategies, while those at later stages enjoy more strategy adaptations (Cavusgil et al., 1993). Moreover, there are also indications that the firm's stage of export development correlates with its degree of control over its export marketing strategy and, therefore, its performance. Novice exporters, who are unfamiliar with international business practices, tend to rely more heavily on guidelines from their foreign customers in designing and implementing their export marketing strategies. However, with more exporting experience, firms gain greater control in managing their international marketing strategies (Wortzel and Wortzel, 1981; Welch and Luostarinen, 1993).

Fifth, although a great number of studies have sought to identify the marketing strategy variables that are conducive to superior export performance, research into low export performance has been virtually neglected. This type of research could pinpoint the strategic determinants of export failure and expose mistakes. It is particularly crucial to investigate this issue during the early stages of exporting, when the risk of failure is greatest (Welch and WiedersheimPaul, 1980). In fact, it has been posited that an initial export failure creates psychological barriers that can result in the firm's delayed progress along the internationalization path, and even its complete withdrawal from overseas business operations (Olson and Wiedersheim-Paul, 1978).

Sixth, future research might examine the concurrent influence of marketing and nonmarketing functions on export performance (Leonidou et al., 1998). Moreover, there is a need to investigate how and to what extent both a particular export marketing strategy and its association with export performance are restricted by its overall competitive strategy (Namiki, 1988, 1989). Further, domestic and export marketing strategies should be examined simultaneously, focusing on their relationship with performance. In this context, comparison of the constituent parts of these strategies can help explain the different ways they affect performance in domestic and export markets (Kamath et al., 1987).

Finally, to improve reliability and promote generalizability of knowledge, it is advisable to undertake (a) replication studies, which can better identify and further refine the strategy-performance relationship at different time and spatial frames, (b) cross-national studies, which can test the validity of this association in different economic, political, technological, and sociocultural settings, (c) singleand related-industry studies, which can investigate the moderating role of various industry-specific parameters, such as industry concentration, production technology, and level of competition, and (d) cross-organizational studies, which can clarify the impact of internal company issues (e.g., age, size, and life-cycle) on the association between strategy variables and performance. Clearly, implementation of these research guidelines requires substantial effort, time, and resources. It would therefore be advisable for this to be undertaken by a multinational consortium of researchers, potentially with the support of an international agency (e.g., OECD, UNCTAD, or WTO) with an interest in promoting exporting among nations.

\section{Studies included in meta analysis}

Amine and Cavusgil, 1986

Atuahene-Gima, 1995

Beamish et al., 1993 
Beamish and Munro, 1993

Bilkey, 1982

Bilkey, 1985

Cavusgil and Zou, 1994

Cooper and Kleinschmidt, 1985

Cunningham and Spigel, 1971

De Luz, 1993

Diamantopoulos and Inglis, 1988

Dominguez and Sequeira, 1993

Donthu and Kim, 1993

Evangelista, 1994

Fenwick and Amine, 1979

Fraser and Hite, 1990

Johnson and Arunthanes, 1995

Karafakioglu, 1986

Katsikeas et al., 1996

Kaynak and Kuan, 1993

Koh and Robicheaux, 1988

Leonidou, 1998

Louter et al., 1991

Madsen, 1987

McDougal and Stening, 1975

McGuiness and Little, 1981

Namiki, 1989

Namiki, 1994

Reid, 1987

Ryans, 1988

Seifert and Ford, 1988

Shoham and Albaum, 1994

Sriram and Manu, 1995

Styles and Amber, 1994

Tookey, 1964

Tyebee, 1994

\section{References}

Aaby NE, Slater SF. Managerial influences on export performance: a review of the empirical literature 1978-88. Int Mark Rev 1989;6(4):53-68.

Albaum G, Strandskov J, Duerr E. International marketing and export management. Harlow, England: Addison-Wesley, 1997.

Amine LS, Cavusgil ST. Export marketing strategies in the British clothing industry. Eur J Mark 1986;20(7):21-33.

Asnoff I. Critique of Henry Mintzberg's 'The design school: reconsidering the basic premises of strategic management'. Strategic Manage J $1991 ; 12: 449-61$.

Axinn CN. Introduction: international perspectives of export marketing. In: Axinn CN, editor. Advances in international marketing (vol. 6). Greenwich, CT: JAI Press, 1994. pp. xi-vi.

Beamish PW, Munro H. The export performance of small and mediumsized Canadian manufacturers. Can J Adm Sci 1986;3(1):29-40.

Bello DC, Barksdale HC. Exporting at industrial trade shows. Ind Mark Manage 1986;3(15):197-206.

BETRO. Concentration on key markets. London: Royal Society of Arts, 1976

Bilkey WJ. Variables associated with export profitability. J Int Bus Stud 1982;(Fall):39-55.

Bilkey WJ. Development of export marketing guidelines. Int Mark Rev 1985;2(1):31-40.
Cateora PR, Graham JL. International marketing. Chicago: Richard D. Irwin, 1999.

Cavusgil ST, Zou S. Marketing strategy-performance relationship: an investigation of the empirical link in export market ventures. J Mark 1994;58(January):1-21.

Cavusgil ST, Zou S, Naidu GM. Product and promotion adaptation in export ventures: an empirical investigation. J Int Bus Stud 1993;24(3): $479-506$

Chetty SK, Hamilton RT. Firm-level determinants of export performance: a meta-analysis. Int Mark Rev 1993;10(3):26-34.

Christensen CH, da Rocha A, Gertner RK. An empirical investigation of the factors influencing exporting success of Brazilian firms. J Int Bus Stud 1987;18(3):61-77

Cooper RG, Kleinschmidt EJ. The impact of export strategy on export sales performance. J Int Bus Stud 1985;16(1):37-55.

Culpan R. Export behavior of firms: relevance of firm size. J Bus Res 1989;(18):207-18.

Cunningham MT, Spigel RI. A study in successful exporting. Br J Mark $1971 ; 2-11$

Czinkota MR, Ronkainen IA. International marketing. Forth Worth, TX: The Dryden Press, 1998.

da Rocha A, Christensen $\mathrm{CH}$. The export experience of a developing country: a review of empirical studies of export behavior and the performance of Brazilian firms. In: Axinn $\mathrm{CN}$, editor. Advances in international marketing (vol. 6). Greenwich, CT: JAI Press, 1994.

De Luz M. Relationship between export strategy variables and export performance of Brazil-based manufacturers. J Global Mark 1993;7(1): $87-110$.

Dess GG, Robinson RB. Measuring organizational performance in the absence of objective measures: the case of privately-held firm and the conglomerate business unit. Strategic Manage J 1984;5:265-73.

Dominguez LV, Sequeira CG. Determinants of LDC exporters' performance: a cross-national study. J Int Bus Stud 1993;24(1):19-40.

Douglas SP, Craig CS. Global marketing strategy. New York: McGrawHill, 1995.

Douglas SP, Wind Y. The myth of globalization. Columbia J World Bus 1987;22(4):19-29.

Evangelista FU. Export performance and its determinants: some empirical evidence from Australian manufacturing firms. In: Axinn $\mathrm{CN}$, editor. Advances in international marketing (vol. 6). Greenwich, CT: JAI Press, 1994. pp. 207-29.

Ford ID, Leonidou LC. Research developments in international marketing. In: Paliwoda SJ, editor. New perspectives on international marketing. London: Routledge, 1991. pp. 3-32.

Gemünden HG. Success factors in export marketing. In: Paliwoda SJ, editor. New perspectives in international marketing. London: Routledge, 1991. pp. 33-62.

Greenley GE. Does strategic planning improve corporate performance? Long Range Plann 1986;19(2):101-9.

Hedges LV, Olkin I. Statistical methods for meta-analysis. New York: Academic Press, 1985.

Holzmüller HH, Kasper H. On the theory of export performance: personal and organizational determinants of export trade activities observed in small and medium-sized firms. Manage Int Rev 1991;(31):45-70.

Johnston WJ, Czinkota MR. Managerial motivations as determinants of industrial export behavior. In: Czinkota MR, Tesar G, editors. Export management: an international context. New York: Praeger Publishers, 1982. pp. 3-17.

Kamath S, Rosson PJ, Patton D, Brooks M. Research on success in exporting: past, present and future. In: Rosson PJ, Reid SD, editors. Managing export entry and expansion. New York: Praeger Publishers, 1987. pp. $398-421$.

Karafakioglu M. Export activities of Turkish manufacturers. Int Mark Rev 1986;(Winter):34-43.

Katsikeas CS, Leonidou LC. Export marketing expansion strategy: differences between market concentration and market spreading. J Mark Manage 1996;12(1-3):113-34. 
Katsikeas CS, Piercy NF, Ioannidis C. Determinants of export performance in a European context. Eur J Mark 1996;30(6):6-35.

Kaynak E, Kothari V. Export behavior of small- and medium-sized manufacturers: some policy guidelines for international marketers. Manage Int Rev 1984;24(2):61-9.

Kaynak E, Kuan WK. Government, strategy, structure, and performance in the context of export activity: an empirical study of Taiwanese manufacturing firms. J Bus Res 1993;(27):33-49.

Keegan WJ. Global marketing management. Upper Saddle River, NJ: Prentice-Hall, 1995.

Kirpalani VH, Balcome D. International marketing success: on conducting more relevant research. In: Rosson PJ, Reid SD, editors. Managing export entry and expansion: an international context. New York: Praeger Publishers, 1987. pp. 387-97.

Koh CA, Robicheaux RA. Variations in export performance due to differences in export marketing strategy: implications for industrial marketers. J Bus Res 1988;(17):249-58.

Leonidou LC. Organizational determinants of exporting: conceptual, methodological and empirical insights. Manage Int Rev 1998;38(2): $7-52$.

Leonidou LC, Katsikeas CS. The export development process: a review of empirical models. J Int Bus Stud 1996;27(3):545-79.

Leonidou LC, Katsikeas CS, Piercy NF. Identifying managerial influences on exporting: past research and future directions. J Int Mark 1998;6(2): $81-111$.

Louter PJ, Ouwerkerk C, Bakker BA. An inquiry into successful exporting. Eur J Mark 1991;25(6):7-23.

Madsen TK. Empirical export performance studies: a review of conceptualizations and findings. In: Cavusgil ST, editor. Advances in international marketing. Greenwich, CT: JAI Press, 1987. pp. 177-98.

Madsen TK. Successful export marketing management: some empirical evidence. Int Mark Rev 1989;6(4):41-57.

McDougal GHG, Stening BW. Something to think about: identifying the high performance exporter. Can Commer 1975;(December):12-5.

McGuinness NW, Little B. The influence of product characteristics on the export performance of new industrial products. J Mark 1981;45(Spring):110-22.

McGuire J, Schneeweis T, Hill J. An analysis of alternative measures of strategic performance. Adv Strategic Manage 1986;4:127-54.

Miesenböck KJ. Small businesses and exporting: a literature review. Int Small Bus J 1988;6(1):42-61.

Miller CC, Cardinal LB. Strategic planning and firm performance: a synthesis of more than two decades of research. Acad Manage J 1994; 37(6):1649-65 (December).

Mintzberg H. The design school: reconsidering the basic premises of strategic management. Strategic Manage J 1991;(11):171-95.

Mosteller FM, Bush RR. Selected quantitative techniques. In: Lindzey G, editor. Handbook of social psychology (vol. 1). Theory and Method. Cambridge, MA: Addison-Wesley, 1954. pp. 328-31.

Namiki N. Export strategy for small business. J Small Bus Manage 1988; 26(2):32-7.

Namiki $\mathrm{N}$. The impact of competitive strategy on export sales performance: an exploratory study. Mid-Atl J Bus 1989;25(6):21-37.

Namiki N. A taxonomic analysis of export marketing strategy: an exploratory study of US exporters of electronic products. J Global Mark 1994;8(1):27-50.

Olson HC, Wiedersheim-Paul F. Factors affecting the pre-export beha- vior of nonexporting firms. In: Leontiades J, editor. European research in international business. Amsterdam: North-Holland, 1978. pp. $283-305$.

Onkvisit S, Shaw JJ. International marketing: analysis and strategy. Upper Saddle River, NJ: Prentice-Hall, 1997.

Pearce JA, Freeman EB, Robinson RB. The tenuous link between formal strategic planning and financial performance. Acad Manage Rev 1987; (12): $658-75$

Piercy N. Company internationalization: active and reactive exporting. Eur J Mark 1981a;15(3):26-40.

Piercy N. British export market selection and pricing. Ind Mark Manage 1981b;(10):287-97.

Piercy N, Katsikeas CS, Cravens DW. Examining the role of buyer-seller relationships in export performance. J World Bus 1997;32(1):73-86.

Rosenthal R. Meta-analysis procedures for social research. Beverly Hills, CA: Sage, 1986

Rosson PJ, Seringhaus FHR. Visitor and exhibitor interaction at industrial trade fairs. J Bus Res 1995;1(32):81-90.

Rust RT, Lehman DR, Farley JU. Estimating publication bias in metaanalysis. J Mark Res 1990;27(May):220-7.

Samiee S, Anckar P. Currency choice in industrial pricing: a cross-national evaluation. J Mark 1998;62(3):112-27.

Samiee S, Walters P. Rectifying strategic gaps in export management. J Global Mark 1990;4(1):7-37.

Seringhaus FHR, Rosson PJ. Management and performance of international trade fair exhibitors: government stands vs. independent stands. Int Mark Rev 1998;15(5):398-412.

Styles G, Ambler T. Successful export practice: the U.K. experience. Int Mark Rev 1994;11(6):23-47.

Terpstra V, Sarathy R. International marketing. Forth Worth, TX: The Dryden Press, 1997.

Tesar G, Tarleton JS. Comparison of Wisconsin and Virginian small and medium-sized exporters: aggressive and passive exporters. In: Czinkota G, Tesar G, editors. Export management: an international context. New York: Praeger Publishers, 1982. pp. 85-112.

Tookey DA. Factors associated with success in exporting. J Manage Stud. 1964;(March):48-66.

Venkatraman N, Ramanujam V. Measurement of business performance in strategy research. Acad Manage Rev 1986;11(October):801-14.

Venkatraman N, Ramanujam V. Measurement of business economic performance: an examination of method convergence. J Manage 1987;13: $109-22$.

Wachter KW. Disturbed by meta-analysis? Science 1998;241(September 16): $1407-8$.

Welch LS, Luostarinen RK. Inward-outward connections in internationalization. J Int Mark 1993;1(1):44-56.

Welch LS, Wiedersheim-Paul F. Initial exports: a marketing failure? J Manage Stud 1980;(October):333-44.

Wolf FM. Meta-analysis: quantitative method for research synthesis. Beverly Hills, CA: Sage, 1986.

Wortzel LH, Wortzel HV. Export marketing strategies for NIC and LDCbased firms. Columbia J World Bus 1981;(Spring):51-60.

Young S, Hamill J, Wheeler S, Davies JR. International market entry and development. Upper Saddle River, NJ: Prentice-Hall, 1989.

Zou S, Stan S. The determinants of export performance: a review of the empirical literature between 1987 and 1997. Int Mark Rev 1998;15(5): $333-56$. 